\title{
Vladimir M. Turok
}

Prof. Vladimir M. Turok died in Moscow on September 21, 1981, after a long, serious illness. He was a member of the Institute for Slavic and Balkan Studies of the Academy of Sciences of the U.S.S.R. He lived in Vienna for several years after 1920. While there he studied at the University of Vienna, where Karl Grünberg, Max Adler, and Hans Kelsen were among his teachers. Like many functionaries of the young Communist movement from Austria and the Balkans, he lived in the Grinzing barracks. He published an account of his personal encounters during this period in an interesting article entitled "Auf der Straße der Komintern."

While in Vienna Turok also worked for the Balkan Bureau of the Comintern. He had a high opinion of the Austrian working-class movement, with which he had many personal ties. In 1977 the minister of science and research, Dr. Hertha Firnberg, honored him by presenting him a first-class Austrian honor cross for arts and sciences.

Without doubt, Turok was the best specialist on contemporary Austrian history in the U.S.S.R. He published a large number of articles dealing with Austrian historical problems in professional journals in the U.S.S.R., and, in his capacity as professor, he inspired other Soviet historians to do research on Austrian problems. He conscientiously looked upon their work with a critical eye. His friendly disposition won the affection of his students.

Turok's main work was his two -volume Outline of the History of Austria, 1918-1938 (Ocerki istorii Avstrii 1918-1938), which was published by the Academy of Sciences of the U.S.S.R. Press in 1955 and 1962. This study constitutes the first effort in the Soviet Union to undertake a critical investigation of Austrian contemporary history. Unfortunately, although a German translation is at hand, up to now no German edition has been published. The book is centered around the activities of the working-class movement. Much attention is devoted to the struggle for Austrian independence. The complicated problems involving the unity of the anti-fascist efforts of the Socialists and Communists during the period between 1934 and 1938 are treated with understanding and sympathy. In both his book and all his lectures and discussions Turok attributed great importance to the development of an Austrian national consciousness. It is not by mere chance that as early as 1962 he expressed the culmination of his historical knowledge in the following words: "Unfortunately, many politicians in the reactionary camp are again supporting the partisans of revenge, in the vain hope that imperialism will send its armies only to the East. The masses of people of the whole world, however, want no repetition of the destruction of the Second World War, and this time they will not allow history to become a bloody farce." 
In recent years Turok participated in numerous scholarly conferences on the history of the Austro-Hungarian monarchy. His original contributions were as highly regarded in Budapest, Prague, and Warsaw as they were in Vienna. His personal and professional interests, however, also lay in Balkan studies, and his knowledge in this field was admirable. It is actually difficult to determine whether Austrian or Balkan studies lay closer to his heart.

Turok was one of the few non-Austrians appointed to the Scientific Commission for the Investigation of the History of Austria between 1918 and 1938. The members of the Commission, professional historians as well as political leaders, esteemed his contributions as well as his sympathetic and friendly nature. He made many friends in Austria.

Turok was interested in the Austrian History Yearbook and had a high regard for John Rath. He was especially delighted when he had an opportunity to converse with Robert A. Kann. Despite their many differences in opinion, both historians had much in common. Above all, they were both closely bound to the traditions and history of Austria.

Turok was a participant in several international scientific conferences of the Historians of the Working-Class Movement in Linz. At the 1972 meeting he engaged in an interesting debate with Norbert Leser over AustroMarxism. Turok argued that Austro-Marxism was a sociopolitical phenomenon which can be understood only in historical dimensions. He alleged that Lenin had a high regard for many of Otto Bauer's perceptions but sharply rejected others. He refused to condemn Otto Bauer and uncritically to glorify Karl Renner.

The Festschrift for Turok's friend Rudolf Neck (Politik und Gesellschaft im Alten und Neuen Österreich [2 vols., Vienna: Verlag für Geschichte und Politik, 1981]) contains the last published articles of both Robert A. Kann (Vol. II, pp. 341-351) and Vladimir M. Turok (Vol. I, pp. 19-29). On this occasion Turok described some of his experiences in Vienna in the 1920's. As he wrote, he was the only one of the persons mentioned in the article "who was still alive." This "modest contribution to the Festschrift," as he phrased it, makes it possible for us clearly to perceive what a lovable and judicious person we have lost through his death.

Some of Turok's personal friends were fortunate enough as his guests to get to know his unimaginable workroom in his home. Not only the walls but also the tables, the bed, and the floor were covered with books and newspapers, most of them from Austria. Turok liked this frightful disorder, although he often found exactly those books he just then needed. Once when I recommended that he should arrange his books according to a system he became angry and said: "But that you can find in any library." 
In May, 1982, I visited his widow, Koka Antonowa (a well-known Indologist) in Moscow. I found the home unchanged and the books and papers still in disarray. Koka has undertaken the task of sorting Turok's papers and turning the written Nachlaß 3 over to the Academy of Sciences in Moscow.

We shall always think of Prof. Turok as a scholar and as a lovable human being; his great influence will continue to live.

Dokumentationsarchiv des

HERBERT STEINER

Österreichischen Widerstandes 